U. S. DEPARTMENT OF COMMERCE BUREAU OF STANDARDS

\title{
BRASS PIPE NIPPLES
}

\section{COMMERCIAL STANDARD CS10-29}

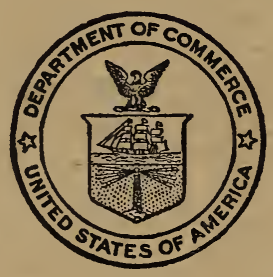

ELIMINATION OF WASTE

Through

SIMPLIFIED COMMERCIAL PRACTICE 
Below are described some of the series of publications of the Department of Commerce which deal with various phases of waste elimination.

\section{Simplified Practice Recommendations.}

These present in detail the development of programs to eliminate unnecessary variety in sizes, dimensions, styles, and types of over 100 commodities. They also contain lists of associations and individuals who have indicated their intention to adhere to the recommendations. These simplified schedules, as formulated and approved by the industries, are indorsed by the Department of Commerce.

\section{Commercial Standards.}

These are developed by various industries under a procedure similar to that of simplified practice recommendations. They are, however, primarily concerned with considerations of grade, quality, and such other characteristics as are outside the scope of dimensional simplification.

\section{American Marine Standards.}

These are promulgated by the American Marine Standards Committee, which is controlled by the marine industry and administered as a unit of the division of simplified practice. Their object is to promote economy in construction, equipment, maintenance, and operation of ships. In general, they provide for simplification and improvement of design, interchangeability of parts, and minimum requisites of quality for efficient and safe operation.

Lists of the publications in each of the above series can be obtained by applying to the Commercial Standards Group, Bureau of Standards, Washington, D. C. 
U. S. DEPARTMENT OF COMMERCE

R. P. LAMONT, Secretary

BUREAU OF STANDARDS

GEORGE K. BURGESS, Director

\section{BRASS PIPE NIPPLES}

\section{COMMERCIAL STANDARD CS10-29}

Effective Date July 1, 1929

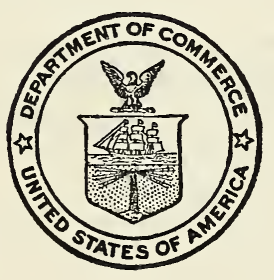

Price 5 Cents

UNITED STATES

GOVERNMENT PRINTING OFFICE

WASHINGTON : 1929 


\section{CONTENTS}

List of acceptors

Commercial standard

Scope

General requirements

General conference

Standing committee.

Certification

Commercial standards procedure

Organization and duties of standing committee

Your cooperation

List of commercial standards

(II) 


\section{COMMERCIAL STANDARD CS10-29}

\section{ACCEPTED BY}

\section{ASSOCIATIONS}

American Hotel Association.

American Oil Burner Association (Inc.). American Society of Sanitary Engineering.

American Specification Institute, The.

National Association of Master Plumbers.

National Association of Purchasing Agents (Inc.).

\section{INDIVIDUALS}

American Tube Works, Boston, Mass. Arnold Nipple Manufacturing Co., Chicago, Ill.

Atkins Manufacturing Co. (Inc.), H. C., St. Louis, Mo.

Ballantine, Benjamin D., Fitchburg, Mass.

Bridgeport Brass Co., Bridgeport, Conn.

City of Pittsburgh, Pa.

Cressman Co., N. C., Philadelphia, Pa. Franklin Plumbing Supply Co. (Inc.), Abilene, Tex.

Fretz \& Co., S. S., jr., Philadelphia, Pa., Hunt Co., H. W., Reading, Mass.

Iroquois Nipple Works, Buffalo, N. Y. Jackwill Nipple Corporation, New York, N. Y.

Lansdale Nipple Co., Lansdale, Pa.

New York Brass Foundry Co., New York, N. Y.
Pabst Co., Fred, Milwaukee, Wis.

Pacific Coast Coal \& Cement Co., Seattle, Wash.

Pipe Nipple Standards Corporation, Chicago, Ill.

Sherman Manufacturing Co., H. B., Battle Creek, Mich.

Shoe-Leather Co., Jersey City, N. J.

Smith Bros. Nipple Works, Hamburg, $\mathrm{Pa}$.

Ware Coupling \& Nipple Co., Ware, Mass.

Waynesboro Nipple Works (Inc.), Waynesboro, $\mathrm{Pa}$.

Woodrow Nipple Manufacturing Co., Chicago, Ill.

\section{GOVERNMENT}

Department of the Interior, Washington, D. C.

District of Columbia, Government of, Washington, D. C.

General Supply Committee, Washington, D. C.

Navy Department, Washington, D. C.

Treasury Department, Washington, D. C.

United States Shipping Board Merchant Fleet Corporation, Washington, D. C.

United States Veterans' Bureau, Washington, D. C. 


\section{BRASS PIPE NIPPLES}

\section{COMMERCIAL STANDARD CS10-29}

On December 14, 1928, a joint conference of representative manufacturers, general interests, and users adopted a commercial standard for brass pipe nipples. The industry has since accepted and approved for promulgation by the Department of Commerce the standard as shown herein.

This recommendation is effective from July 1, 1929, for new production, and September 1, 1929, for clearance of existing stock.

Promulgation recommended.

R. M. Hudson, Assistant Director, Commercial Standards.

Promulgated.

Geokge K. Burgess, Director Bureau of Standards.

ApPRoved.

R. P. Lamont, Secretary of Commerce.

(1) 


\section{SCOPE}

This commercial standard covers brass pipe nipples made from three grades of brass pipe, red brass, yellow brass, and Muntz metal designated as grades A, B, and C, respectively. Each grade is furnished in two weights, standard and extra strong.

\section{GENERAL REQUIREMENTS}

Brass pipe nipples shall be made only from tested new full weight brass pipe, clean, smooth, round, straight, and of the proper dimensions. Free from grooving, indentations, cracks, flaws, or any other defects which might affect its strength or serviceability.

Weight and gage variations for brass pipe from which brass nipples may be made shall be as stated in United States Government Master Specification 342a for pipe, brass, seamless, iron pipe size, standard and extra strong, as follows:

One cubic inch of grade A material is assumed to weigh 0.313 pound. One cubic inch of grades B and C material is assumed to weigh 0.307 pound. No single piece that exceeds the calculated weight by more than 5 per cent shall be accepted. The tolerance for underweight and gage shall be $\mathbf{5}$ per cent for pipe up to and including 6 inches; 7 per cent from 6 inches to and including 8 inches; and 8 per cent above 8 inches, respectively.

All pipe used in the manufacture of nipples shall be furnished semiannealed, unless otherwise specified, and shall be acid cleaned.

Seamless brass pipe shall be made of material conforming in composition to the requirements in Table 1.

TABLE 1.-Chemical composition of brass pipe

\begin{tabular}{|c|c|c|c|c|c|}
\hline Grade & Trade name & Copper & Zinc & $\begin{array}{l}\text { Lead } \\
\text { (maxi- } \\
\text { mum) }\end{array}$ & $\begin{array}{l}\text { Iron } \\
\text { (maxi- } \\
\text { mum) }\end{array}$ \\
\hline $\begin{array}{l}\mathrm{A} \\
\mathrm{B} \\
\mathrm{B}\end{array}$ & $\begin{array}{l}\text { Red brass } \\
\text { Yellow brass } \\
\text { Muntz metal..... }\end{array}$ & $\begin{array}{c}\text { Per cent } \\
79-86 \\
65-68 \\
59-68\end{array}$ & $\begin{array}{c}\text { Per cent } \\
\text { Remainder-ado }\end{array}$ & $\begin{array}{c}\text { Per cent } \\
0.20 \\
.80 \\
.80\end{array}$ & $\begin{array}{c}\text { Per cent } \\
0.05 \\
.07 \\
.07\end{array}$ \\
\hline
\end{tabular}

The dimensions, weights, and number of threads per inch of the various sizes of pipe nipples when ordered as standard iron-pipe size, regular, shall be as shown in Table 2 . 
TABLE 2.-Standard weights and dimensions of brass pipe nipples, iron-pipe size

\begin{tabular}{|c|c|c|c|c|c|c|c|}
\hline \multicolumn{3}{|c|}{ Diameter } & \multirow[b]{2}{*}{$\begin{array}{l}\text { Thick- } \\
\text { ness }\end{array}$} & \multicolumn{2}{|c|}{$\begin{array}{l}\text { Nominal weight } \\
\text { per foot }\end{array}$} & \multirow{2}{*}{$\begin{array}{l}\text { Minimum } \\
\text { internal } \\
\text { hydro- } \\
\text { static test } \\
\text { pressure }\end{array}$} & \multirow[b]{2}{*}{$\begin{array}{l}\text { Threads } \\
\text { per inch }\end{array}$} \\
\hline $\begin{array}{l}\text { Iron- } \\
\text { pipe } \\
\text { size }\end{array}$ & $\begin{array}{l}\text { Nominal } \\
\text { outside }\end{array}$ & $\begin{array}{c}\text { Nominal } \\
\text { inside }\end{array}$ & & $\begin{array}{c}\text { Grade A } \\
\text { (plain } \\
\text { ends) }\end{array}$ & $\begin{array}{c}\text { Grades } \\
\text { B and C } \\
\text { (plain } \\
\text { ends) }\end{array}$ & & \\
\hline $\begin{array}{c}\text { Inches } \\
1 / 8 \\
1 / 4 \\
3 / 8 \\
1 / 2 \\
3 / 4\end{array}$ & $\begin{array}{r}\text { Inches } \\
0.405 \\
.540 \\
.675 \\
.840 \\
1.050\end{array}$ & $\begin{array}{r}\text { Inches } \\
0.281 \\
.375 \\
.494 \\
.625 \\
.822\end{array}$ & $\begin{array}{c}\text { Inch } \\
0.0620 \\
.0825 \\
.0905 \\
.1075 \\
.1140\end{array}$ & $\begin{array}{c}\text { Pounds } \\
0.251 \\
.445 \\
.624 \\
.93 \\
1.26\end{array}$ & $\begin{array}{c}\text { Pounds } \\
0.246 \\
.437 \\
.612 \\
.911 \\
1.24\end{array}$ & $\begin{array}{c}\text { Lbs./in. }{ }^{2} \\
1,000 \\
1,000 \\
1,000 \\
1,000 \\
1,000\end{array}$ & $\begin{array}{l}27 \\
18 \\
18 \\
14 \\
14\end{array}$ \\
\hline $\begin{array}{l}1 \\
11 / 4 \\
11 / 2 \\
2 \\
21 / 2\end{array}$ & $\begin{array}{l}1.315 \\
1.660 \\
1.900 \\
2.375 \\
2.875\end{array}$ & $\begin{array}{l}\text { 1. } 062 \\
\text { 1. } 368 \\
\text { 1. } 600 \\
\text { 2. } 062 \\
\text { 2. } 500\end{array}$ & $\begin{array}{l}.1265 \\
.1460 \\
.1500 \\
.1565 \\
.1875\end{array}$ & $\begin{array}{l}\text { 1. } 77 \\
2.61 \\
3.10 \\
4.10 \\
5.94\end{array}$ & $\begin{array}{l}1.74 \\
2.56 \\
3.04 \\
4.02 \\
5.83\end{array}$ & $\begin{array}{l}1,000 \\
1,000 \\
1,000 \\
1,000 \\
1,000\end{array}$ & $\begin{array}{c}111 / 2 \\
111 / 2 \\
111 / 2 \\
111 / 2 \\
8\end{array}$ \\
\hline $\begin{array}{l}3 \\
31 / 2 \\
4 \\
5\end{array}$ & $\begin{array}{l}3.500 \\
4.000 \\
4.500 \\
5.563\end{array}$ & $\begin{array}{l}\text { 3. } 062 \\
3.500 \\
4.000 \\
5.062\end{array}$ & $\begin{array}{l}.2190 \\
.2500 \\
.2500 \\
.2505\end{array}$ & $\begin{array}{r}8.47 \\
11.06 \\
12.53 \\
15.70\end{array}$ & $\begin{array}{r}8.31 \\
10.85 \\
12.29 \\
15.40\end{array}$ & $\begin{array}{r}1,000 \\
1,000 \\
900 \\
700\end{array}$ & $\begin{array}{l}8 \\
8 \\
8 \\
8\end{array}$ \\
\hline $\begin{array}{r}6 \\
8 \\
10\end{array}$ & $\begin{array}{r}6.625 \\
8.625 \\
10.750\end{array}$ & $\begin{array}{r}6.125 \\
8.000 \\
10.019\end{array}$ & $\begin{array}{l}.2500 \\
.3125 \\
.3655\end{array}$ & $\begin{array}{l}\text { 18. } 80 \\
30.63 \\
44.75\end{array}$ & $\begin{array}{l}18.44 \\
30.05 \\
43.91\end{array}$ & $\begin{array}{l}600 \\
500 \\
500\end{array}$ & $\begin{array}{l}8 \\
8 \\
8\end{array}$ \\
\hline
\end{tabular}

The dimensions, weights, and number of threads per inch of the various sizes of pipe nipples when ordered as extra strong, shall be as shown in Table 3.

TABLE 3.-Weights and dimensions of brass pipe nipples iron pipe size extra strong

\begin{tabular}{|c|c|c|c|c|c|c|c|}
\hline \multicolumn{3}{|c|}{ Diameter } & \multirow{2}{*}{$\begin{array}{l}\text { Thick- } \\
\text { ness }\end{array}$} & \multicolumn{2}{|c|}{$\begin{array}{l}\text { Nominal weight } \\
\text { per foot }\end{array}$} & \multirow{2}{*}{$\begin{array}{c}\text { Minimum } \\
\text { internal } \\
\text { hydro- } \\
\text { static } \\
\text { test } \\
\text { pressure }\end{array}$} & \multirow{2}{*}{$\begin{array}{c}\text { Number } \\
\text { of } \\
\text { threads } \\
\text { per inch }\end{array}$} \\
\hline $\begin{array}{l}\text { Iron } \\
\text { pipe } \\
\text { size }\end{array}$ & $\begin{array}{l}\text { Nominal } \\
\text { outside }\end{array}$ & $\begin{array}{c}\text { Nominal } \\
\text { inside }\end{array}$ & & $\begin{array}{l}\text { Grade } \\
\text { A } \\
\text { (plain } \\
\text { ends) }\end{array}$ & $\begin{array}{c}\text { Grades } \\
\text { B and C } \\
\text { (plain } \\
\text { ends) }\end{array}$ & & \\
\hline $\begin{array}{r}\text { Inches } \\
1 / 8 \\
1 / 4 \\
3 / 8 \\
1 / 2 \\
3 / 4\end{array}$ & $\begin{array}{r}\text { Inches } \\
0.405 \\
.540 \\
.675 \\
.840 \\
1.050\end{array}$ & $\begin{array}{r}\text { Inches } \\
0.205 \\
.294 \\
.421 \\
.542 \\
.736\end{array}$ & $\begin{array}{c}\text { Inch } \\
0.100 \\
.123 \\
: 127 \\
.149 \\
.157\end{array}$ & $\begin{array}{c}\text { Pounds } \\
0.360 \\
.605 \\
.821 \\
1.21 \\
1.65\end{array}$ & $\begin{array}{c}\text { Pounds } \\
0.353 \\
.593 \\
.805 \\
1.19 \\
1.62\end{array}$ & $\begin{array}{r}\text { Lbs./in. }{ }^{2} \\
1,000 \\
1,000 \\
1,000 \\
1,000 \\
1,000\end{array}$ & $\begin{array}{l}27 \\
18 \\
18 \\
14 \\
14\end{array}$ \\
\hline $\begin{array}{l}1 \\
11 / 4 \\
11 / 2 \\
2 \\
21 / 2\end{array}$ & $\begin{array}{l}1.315 \\
1.660 \\
1.900 \\
2.375 \\
2.875\end{array}$ & $\begin{array}{l}.951 \\
1.272 \\
1.494 \\
1.933 \\
2.315\end{array}$ & $\begin{array}{l}.182 \\
.194 \\
.203 \\
.221 \\
.280\end{array}$ & $\begin{array}{l}2.43 \\
\text { 3. } 36 \\
4.07 \\
5.62 \\
8.58\end{array}$ & $\begin{array}{l}2.39 \\
3.30 \\
3.99 \\
5.51 \\
8.41\end{array}$ & $\begin{array}{l}1,000 \\
1,000 \\
1,000 \\
1,000 \\
1,000\end{array}$ & $\begin{array}{l}111 / 2 \\
111 / 2 \\
111 / 2 \\
111 / 2 \\
8\end{array}$ \\
\hline $\begin{array}{l}3 \\
31 / 2 \\
4 \\
5\end{array}$ & $\begin{array}{l}3.500 \\
4.000 \\
4.500 \\
5.563\end{array}$ & $\begin{array}{l}2.892 \\
\text { 3. } 358 \\
\text { 3. } 818 \\
4.813\end{array}$ & $\begin{array}{l}.304 \\
.321 \\
.341 \\
.375\end{array}$ & $\begin{array}{l}11.46 \\
13.93 \\
16.73 \\
22.95\end{array}$ & $\begin{array}{l}11.24 \\
13.67 \\
16.41 \\
22.52\end{array}$ & $\begin{array}{l}1,000 \\
1,000 \\
1,000 \\
1,000\end{array}$ & $\begin{array}{l}8 \\
8 \\
8 \\
8\end{array}$ \\
\hline $\begin{array}{r}6 \\
8 \\
10\end{array}$ & $\begin{array}{r}6.625 \\
8.625 \\
10.750\end{array}$ & $\begin{array}{l}5.750 \\
7.625 \\
9.750\end{array}$ & $\begin{array}{l}.437 \\
.500 \\
.500\end{array}$ & $\begin{array}{l}31.92 \\
47.92 \\
60.45\end{array}$ & $\begin{array}{l}31.32 \\
47.02 \\
59.32\end{array}$ & $\begin{array}{r}1,000 \\
900 \\
700\end{array}$ & $\begin{array}{l}8 \\
8 \\
8\end{array}$ \\
\hline
\end{tabular}


Pipe nipples shall be threaded right hand, unless otherwise ordered, on both ends in accordance with the American standard for pipe thread B-2-1919 of the American Standard Association.

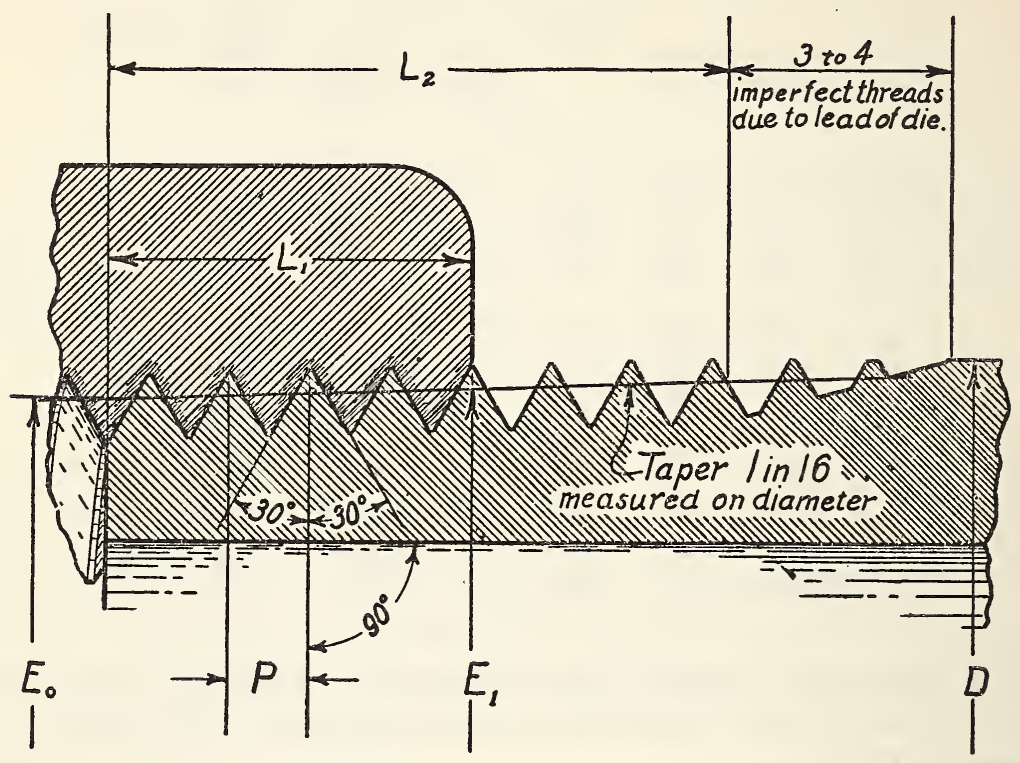

FIgURE 1.-Taper pipe threads

$E_{0}=$ pitch diameter of thread at end of pipe. $=D-(0.05 D+1.1) P$.

$D=$ outside diameter of pipe.

$L_{2}=$ length of effective thread (threads perfect at

$=\left(\begin{array}{l}\text { root }) \\ =.8 D+6.8) P .\end{array}\right.$
Depth of thread $=0.8 P$.

$E_{1}=$ Pitch diameter of thread at gauging notch. $=\mathrm{E}_{0}+0.0625 \mathrm{~L}_{1}$.

$L_{1}=$ normal engagement by hand between external and internal threads.

$P=$ pitch of thread.

TABLE 4.-Taper pipe thread dimensions

\begin{tabular}{|c|c|c|c|c|c|c|c|}
\hline $\begin{array}{l}\text { Iron } \\
\text { pipe } \\
\text { size }\end{array}$ & $\begin{array}{l}\text { Number } \\
\text { of threads } \\
\text { per inch }\end{array}$ & $\begin{array}{l}\text { Depth of } \\
\text { thread }\end{array}$ & $D$ & $L_{1}$ & $L_{2}$ & $E_{0}$ & $E_{1}$ \\
\hline 1 & 2 & 3 & 4 & 5 & 6 & 7 & 8 \\
\hline $\begin{array}{r}\text { Inches } \\
1 / 8 \\
1 / 4 \\
3 / 8 \\
1 / 2 \\
3 / 4\end{array}$ & $\begin{array}{l}27 \\
18 \\
18 \\
14 \\
14\end{array}$ & $\begin{array}{l}\text { Inch } \\
0.02963 \\
.04444 \\
.04444 \\
.05714 \\
.05714\end{array}$ & $\begin{array}{r}\text { Inches } \\
0.405 \\
.540 \\
.675 \\
.840 \\
1.050\end{array}$ & $\begin{array}{r}\text { Inches } \\
0.180 \\
.200 \\
.240 \\
.320 \\
.339\end{array}$ & $\begin{array}{l}\text { Inches } \\
0.26385 \\
.40178 \\
.40778 \\
.53371 \\
.54571\end{array}$ & $\begin{array}{l}\text { Inches } \\
0.36351 \\
.47739 \\
.61201 \\
.75843 \\
.96768\end{array}$ & $\begin{array}{l}\text { Inches } \\
0.37476 \\
.48989 \\
.62701 \\
.77843 \\
.98887\end{array}$ \\
\hline $\begin{array}{l}1 \\
11 / 4 \\
11 / 2 \\
2\end{array}$ & $\begin{array}{l}111 / 2 \\
111 / 2 \\
111 / 2 \\
111 / 2\end{array}$ & $\begin{array}{l}.06957 \\
.06957 \\
.06957 \\
.06957\end{array}$ & $\begin{array}{l}1.315 \\
1.660 \\
1.900 \\
2.375\end{array}$ & $\begin{array}{l}.400 \\
.420 \\
.420 \\
.436\end{array}$ & $\begin{array}{l}.68278 \\
.70678 \\
.72348 \\
.75652\end{array}$ & $\begin{array}{l}\text { 1. } 21363 \\
\text { 1. } 55713 \\
\text { 1. } 79609 \\
2.26902\end{array}$ & $\begin{array}{l}1.23863 \\
1.58338 \\
1.82234 \\
2.29627\end{array}$ \\
\hline $\begin{array}{l}21 / 2 \\
3 \\
31 / 2 \\
4\end{array}$ & $\begin{array}{l}8 \\
8 \\
8 \\
8\end{array}$ & $\begin{array}{l}.10000 \\
.10000 \\
.10000 \\
.10000\end{array}$ & $\begin{array}{l}2.875 \\
3.500 \\
4.000 \\
4.500\end{array}$ & $\begin{array}{l}.682 \\
.766 \\
.821 \\
.844\end{array}$ & $\begin{array}{l}1.13750 \\
1.20000 \\
1.25000 \\
1.30000\end{array}$ & $\begin{array}{l}\text { 2. } 71953 \\
\text { 3. } 34062 \\
\text { 3. } 83750 \\
4.33438\end{array}$ & $\begin{array}{l}\text { 2. } 76216 \\
\text { 3. } 38850 \\
\text { 3. } 88881 \\
4.38712\end{array}$ \\
\hline $\begin{array}{r}5 \\
6 \\
8 \\
10\end{array}$ & $\begin{array}{l}8 \\
8 \\
8 \\
8\end{array}$ & $\begin{array}{l}.10000 \\
.10000 \\
.10000 \\
.10000\end{array}$ & $\begin{array}{r}5.563 \\
6.625 \\
8.625 \\
10.750\end{array}$ & $\begin{array}{r}.937 \\
.958 \\
1.063 \\
1.210\end{array}$ & $\begin{array}{l}1.40630 \\
1.51250 \\
1,71250 \\
1.92500\end{array}$ & $\begin{array}{r}5.39073 \\
6.44609 \\
8.43359 \\
10.54531\end{array}$ & $\begin{array}{r}5.44929 \\
6.50597 \\
8.50003 \\
10.62094\end{array}$ \\
\hline
\end{tabular}

NOTE.-The dimensions of American standard pipe threads are expressed in inches to one one-hundredth thousandth $(0.00001)$ of an inch. While this is a greater degree of accuracy than is ordinarily used, the dimensions are so expressed in order to eliminate errors which might result from less accurate dimensions. 
Where straight pipe threads are specified the following shall apply:

(a) The sizes and basic dimensions of straight pipe threads shall be as given in columns 1, 2, 3, and 8 of Table 4 .

(b) Diameters of straight threads. The basic pitch diameter of the straight thread shall be equal to the diameter at the gaging notch of taper pipe thread plug gage, and shall be determined by the following formula (see symbols above):

$$
E_{1}=D-(0.05 D+1.1) P+0.0625 L_{1}
$$

Gages used for inspection shall not vary from the basic dimensions more than one-half turn either way.

Inspection tolerances.-The maximum allowable variation in the commercial product is one turn plus or one turn minus from the gaging notch when using gages. This is equivalent to a maximum allowable variation of one and one-half turns from the basic dimensions, owing to the allowance of one-half turn on the gages.

Ends of nipples shall be cut square to the central axis and shall be reamed inside and chamfered outside at an angle of $25^{\circ}$ to $45^{\circ}$ to the central axis.

Nipples shall not exceed one-sixteenth of an inch under or over the specified length.

Brass pipe nipples are regularly made and stocked in the sizes given in Tables 5 to 8 , inclusive.

It is recommended that the use of fine thread nipples be discouraged because of the extra cost of manufacture and handling and the evident decline in their use.

TABLE 5.-Stock sizes of standard weight

\begin{tabular}{|c|c|c|c|c|}
\hline $\begin{array}{l}\text { Iron } \\
\text { pipe } \\
\text { size }\end{array}$ & Close & $\begin{array}{l}\text { Special } \\
\text { short }\end{array}$ & Short & Long \\
\hline $\begin{array}{c}\text { Inches } \\
1 / 8 \\
1 / 4 \\
3 / 8 \\
1 / 2 \\
3 / 4\end{array}$ & $\begin{array}{r}\text { Inches } \\
3 / 4 \\
7 / 8 \\
1 \\
11 / 8 \\
13 / 8\end{array}$ & $\begin{array}{c}\text { Inches } \\
1 \\
11 / 4 \\
11 / 2\end{array}$ & $\begin{array}{r}\text { Inches } \\
11 / 2 \\
11 / 2 \\
11 / 2 \\
11 / 2 \\
2\end{array}$ & $\begin{array}{l}\text { Inches } \\
2,21 / 2,3,31 / 2,4,41 / 2,5,51 / 2 \text {, and } 6 . \\
2,21 / 2,3,31 / 2,4,41 / 2,5,51 / 2, \text { and } 6 . \\
2,21 / 2,3,31 / 2,4,41 / 2,5,51 / 2, \text { and } 6 . \\
2,21 / 2,3,31 / 2,4,41 / 2,5,51 / 2 \text {, and } 6 . \\
21 / 2,3,31 / 2,4,41 / 2,5,51 / 2, \text { and } 6 .\end{array}$ \\
\hline $\begin{array}{l}1 \\
11 / 4 \\
11 / 2 \\
2 \\
21 / 2\end{array}$ & $\begin{array}{l}11 / 2 \\
15 / 8 \\
13 / 4 \\
2 \\
21 / 2\end{array}$ & $\begin{array}{l}2 \\
2\end{array}$ & $\begin{array}{l}2 \\
21 / 2 \\
21 / 2 \\
21 / 2 \\
3\end{array}$ & $\begin{array}{l}21 / 2,3,31 / 2,4,41 / 2,5,51 / 2, \text { and } 6 . \\
3,31 / 2,4,41 / 2,5,51 / 2, \text { and } 6 . \\
3,31 / 2,4,41 / 2,5,51 / 2 \text {, and } 6 . \\
3,31 / 2,4,41 / 2,5,51 / 2, \text { and } 6 . \\
31 / 2,4,41 / 2,5,51 / 2, \text { and } 6 .\end{array}$ \\
\hline $\begin{array}{l}3 \\
4 \\
5 \\
6\end{array}$ & $\begin{array}{l}25 / 8 \\
27 / 8 \\
3 \\
31 / 8\end{array}$ & $\begin{array}{l}4 \\
4\end{array}$ & $\begin{array}{l}3 \\
4 \\
41 / 2 \\
41 / 2\end{array}$ & $\begin{array}{l}31 / 2,4,41 / 2,5,51 / 2, \text { and } 6 . \\
41 / 2,5,51 / 2, \text { and } 6 . \\
5,51 / 2, \text { and } 6 . \\
5,51 / 2, \text { and } 6 .\end{array}$ \\
\hline
\end{tabular}

$53396^{\circ}-29-2$ 
TABLE 6.-Stock sizes of extra sirong

\begin{tabular}{|c|c|c|c|}
\hline $\begin{array}{l}\text { Iron } \\
\text { pipe } \\
\text { size }\end{array}$ & Close & Short & Long \\
\hline $\begin{array}{c}\text { Inches } \\
1 / 8 \\
1 / 4 \\
3 / 8 \\
1 / 2 \\
3 / 4\end{array}$ & $\begin{array}{c}\text { Inches } \\
3 / 4 \\
7 / 8 \\
1 \\
11 / 8 \\
13 / 8\end{array}$ & \begin{tabular}{|c|} 
Inches \\
\\
\\
\\
2
\end{tabular} & $\begin{array}{c}\text { Inches } \\
2,3,4,5 \text {, and } 6 . \\
2,3,4,5 \text {, and } 6 . \\
2,3,4,5 \text {, and } 6 . \\
2,3,4,5 \text {. } \\
3,4,5 \text {, and } 6 \text {. }\end{array}$ \\
\hline $\begin{array}{l}1 \\
11 / 4 \\
11 / 2 \\
2\end{array}$ & $\begin{array}{l}11 / 2 \\
158 \\
13 / 4 \\
2\end{array}$ & \begin{tabular}{c}
2 \\
\hdashline \\
\end{tabular} & $\begin{array}{l}3,4,5, \text { and } 6 . \\
3,4,5 \text {, and } 6 . \\
3,4,5, \text { and } 6 . \\
3,4,5, \text { and } 6 .\end{array}$ \\
\hline
\end{tabular}

TABLE 7.-Stock sizes of right and left, standard weight. (Threaded right hand on one end, left hand on the other.)

\begin{tabular}{|c|c|c|}
\hline $\begin{array}{l}\text { Iron } \\
\text { pipe } \\
\text { size }\end{array}$ & Short & Long \\
\hline $\begin{array}{c}\text { Inches } \\
3 / 8 \\
1 / 2 \\
3 / 4 \\
11 \\
11 / 4 \\
11 / 2 \\
2\end{array}$ & $\begin{array}{l}\text { Inches } \\
2 \\
2\end{array}$ & $\begin{array}{l}\text { Inches } \\
2,3,4,5 \text {, and } 6 . \\
2,3,4,5 \text {, and } 6 . \\
3,4,5, \text { and } 6 . \\
3,4,5 \text {, and } 6 . \\
3,4,5 \text {, and } 6 . \\
3,4,5, \text { and } 6 . \\
3,4,5, \text { and } 6 .\end{array}$ \\
\hline
\end{tabular}

TABLE 8.-Stock sizes of standard weight

(Contained in carton)

\begin{tabular}{|c|c|c|c|c|c|c|c|c|c|c|c|c|}
\hline \multirow{2}{*}{$\begin{array}{l}\text { Iron } \\
\text { pipe } \\
\text { size }\end{array}$} & \multirow{2}{*}{ Close } & \multicolumn{10}{|c|}{ Long (in inches) } & \multirow{2}{*}{ Total } \\
\hline & & $11 / 2$ & 2 & $21 / 2$ & 3 & $31 / 2$ & 4 & $41 / 2$ & 5 & $51 / 2$ & 6 & \\
\hline $\begin{array}{l}\text { Inch } \\
3 / 8 \\
1 / 2 \\
3 / 4 \\
1^{3 / 4}\end{array}$ & $\begin{array}{l}20 \\
20 \\
20 \\
15\end{array}$ & $\begin{array}{l}10 \\
10 \\
10\end{array}$ & $\begin{array}{l}15 \\
15 \\
15 \\
12\end{array}$ & $\begin{array}{r}10 \\
10 \\
10 \\
5\end{array}$ & $\begin{array}{l}10 \\
10 \\
10 \\
12\end{array}$ & $\begin{array}{l}5 \\
5 \\
5 \\
3\end{array}$ & $\begin{array}{l}10 \\
10 \\
10 \\
12\end{array}$ & $\begin{array}{l}5 \\
5 \\
5 \\
3\end{array}$ & $\begin{array}{l}5 \\
5 \\
5 \\
5\end{array}$ & $\begin{array}{l}5 \\
5 \\
5 \\
3\end{array}$ & $\begin{array}{l}5 \\
5 \\
5 \\
5\end{array}$ & $\begin{array}{r}100 \\
100 \\
100 \\
75\end{array}$ \\
\hline $\begin{array}{l}3 / 8 \\
1 / 2 \\
3 / 4 \\
1\end{array}$ & $\begin{array}{l}12 \\
12 \\
12 \\
10\end{array}$ & $\begin{array}{r}5 \\
5 \\
5 \\
\end{array}$ & $\begin{array}{r}5 \\
5 \\
5 \\
10\end{array}$ & $\begin{array}{l}5 \\
5 \\
5 \\
5\end{array}$ & $\begin{array}{l}5 \\
5 \\
5 \\
5\end{array}$ & $\begin{array}{l}5 \\
5 \\
5 \\
3\end{array}$ & $\begin{array}{l}5 \\
5 \\
5 \\
5\end{array}$ & $\begin{array}{l}2 \\
2 \\
2 \\
2\end{array}$ & $\begin{array}{l}2 \\
2 \\
2 \\
4\end{array}$ & $\begin{array}{l}2 \\
2 \\
2 \\
2\end{array}$ & $\begin{array}{l}2 \\
2 \\
2 \\
4\end{array}$ & $\begin{array}{l}50 \\
50 \\
50 \\
50\end{array}$ \\
\hline
\end{tabular}

\section{GENERAL CONFERENCE}

Pursuant to a request from interested manufacturers, a general conference of representative producers, users, and general interests was held on December 14, 1928, at the William Penn Hotel, Pittsburgh, Pa., to consider the establishment of a commercial standard for brass pipe nipples (I. P. S.) on the basis of a preliminary draft prepared by the committee of producers. The following individuals were present:

Armstrong, Julian, executive vice president, Pipe Nipple Standards Corporation.

Chasnoff, A., president, Jackwell Nipple Corporation. 
Davia, A., purchasing agent, Dravo Contracting Co.

English, Thomas G., assistant chief plumbing inspector, city of Pittsburgh, Pa.

Groff, Raymond, vice president, S. S. Fretz, jr., \& Co.

Howe, Donald W., treasurer, Ware Coupling \& Nipple Co.

Hunt, H. W., treasurer, H. W. Hunt Co.

Lee, Thomas J., plumbing inspector, American Society of Sanitary Engineering.

Marlor, Elmer F., sales representative, Smith Bros. Nipple Works.

Poole, Frank H., president, Lansdale Nipple Co.

Shoz, R. B., president, Shoe-Letcher Co.

Walther, W. J., sales manager, Woodrow Nipple Manufacturing Co.

Webster, W. R., representing American Society for Testing Materials and

Bridgeport Brass Co.

Wiedeman, F. M., vice president and general manager, Fred Pabst Co.

Williams, Dixon C., president, Chicago Nipple Manufacturing Co.

FAIRCHILD, I. J., commercial standards unit, Bureau of Standards.

RAY, Wilson K., district manager, Bureau of Foreign and Domestic Commerce.

Julian Armstrong presented the proposed commercial standard for brass pipe nipples and outlined briefly the plan which has been inaugurated by the Pipe Nipple Standards Corporation for certifying compliance to the standard; that is, a trade-mark symbol which will be applied to the pipe nipples themselves, or to the carton in case of close and short nipples. This trade-mark is a guaranty by the producer and by the Pipe Nipple Standards Corporation that the product so marked is in strict conformity with the requirements and tests of the commercial standard. Each producer subscribing to this means of certification submits to periodical and unannounced inspection of his product at any time by representatives of the Pipe Nipple Standards Corporation.

The conference adopted unanimously several minor modifications and upon motion by Mr. Howe, seconded by Mr. Lee, it was voted unanimously to adopt the proposed commercial standard for brass pipe nipples (I. P. S.) as revised.

Upon motion by Mr. Armstrong, seconded by Mr. Wiedeman, the conference voted unanimously to request the Bureau of Standards to operate the certification plan on the basis of this commercial standard.

The conference set July 1, 1929, as the effective date for new production, and September 1, 1929, as effective date for clearance of existing stocks. It was understood that the normal revision interval shall be one year.

\section{STANDING COMMITTEE}

The following standing committee was appointed with unanimous consent:

D. W. Howe, Ware Coupling \& Nipple Co.

R. B. Shoe, Shoe-Letcher Co.

W. G. Cornell Co., of New York, N. Y.

Crane Co. 
Allen \& Reeves (Inc.), Providence, R. I.

Thomas J. Lee, American Society of Sanitary Engineering.

George H. Drake, National Association of Master Plumbers.

Thomas G. English, department of public health, bureau of sanitation, city of Pittsburgh.

Wilson K. Ray, district manager, bureau of Foreign and Domestic Commerce of Pittsburgh, Pa., read a report from M. H. Bletz, chief, standards section, Bureau of Foreign and Domestic Commerce, relative to the present exports of brass and bronze pipe fittings and valves and indicated methods by which the industry might have the above commercial standard translated into foreign languages as a means for promoting foreign trade in this commodity.

The conference decided that the translation of the commercial standard should be postponed until a group of standards for various types of pipe fittings can be so translated and issued in a single pamphlet. Another reason indicated for this postponement was the fact that Whitworth threads appeared to predominate in the South American market.

\section{CERTIFICATION}

The following illustrates how an important group of producers has arranged to certify complete compliance with the specification. Pipe nipples found by this group to conform to this standard may be readily identified by the trade-mark (registered at the United States Patent Office) stamped into the outer surface of the nipples, on the

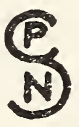

labels of packaged nipples and on labels and tags only of packages of short and close nipples where the threading leaves no space for such marking.

The use of this trade-mark is governed by a license agreement with the Pipe Nipple Standards Corporation, an association whose request led to the establishment of this standard through the United States Department of Commerce. Any manufacturer, whether a member of the corporation or not, who subscribes to the license agreement, which entitles him to use the trade-mark, agrees to follow the commercial standard in full detail, and to accept a periodic inspection provided under this license agreement whereby quality, workmanship, and adherence to the standard are carefully checked. Pipe nipples bearing this trade-mark, or "seal of certainty" as it is called, carry with them the individual producer and the group guaranty that they meet the commercial standard in every detail. 
While other methods may be employed by producers to certify strict conformity to the requirements and tests of the commercial standard for brass pipe nipples, it is claimed by the Pipe Nipple Standards Corporation that this inspection service and group plan is more substantial than assurances or guaranties signed only by an individual producer.

\section{COMMERCIAL STANDARDS PROCEDURE}

Industry has long sensed the need for a wider application and use of specifications developed and approved by nationally recognized organizations. To assist these bodies and the producers and consumersin securing this result and as a natural outgrowth of the movement toward elimination of waste through simplified practice, the Bureau of Standards has set up a procedure under which specifications, properly indorsed, may be printed as official publication of the Department of Commerce and promulgated as "commercial standards." This service parallels that of simplified practice in many respects and is available only upon request.

Broadly speaking, the aim is to continue the same character of cooperative service in this field that is being rendered in simplification. The commercial standards unit is not designed to act as a standardizing body, nor will it engage in the preparation of specifications. Its service is mainly promotional in character, since its chief mission is to get behind a standard or a specification which any industry or its related groups may want to promulgate on a nation-wide basis; to determine its eligibility for promulgation; to publish and broadcast it in the event the prerequisities of procedure have been met, including: a satisfactory majority acceptance; to facilitate the application of the certification plan for the assurance and convenience of the small purchaser; to provide means for periodical audits of adherence; and to cooperate with the Bureau of Foreign and Domestic Commerce in determining the desire of industry relative to translation and promulgation of such specifications as a basis for foreign commerce.

In general, it may be said that a simplification covers types, sizes, and varieties of a commodity which are retained by industry on the basis of demand, whereas a commercial standard establishes definite requirements as to grade, quality, or dimensional tolerances in addition to any limitation of variety desired and accepted by the industry.

\section{ORGANIZATION AND DUTIES OF STANDING COMMITTEE}

At the close of its session each general conference appoints a permanent standing committee, composed of not more than three representatives from each phase of the industry; for example, producers, distributors, and consumers. 
The proper functioning of the committee requires that its members be able to attend in person meetings held at some central place. They. must also be prepared to devote the necessary time and to accept such assignments and responsibilities as may be found requisite to the success of the program.

Because the department in no case assumes the prerogative of taking final action in connection with a commercial standard, it is essential that there be some avenue through which the industry can be consulted promptly and can, in turn, make known its wishes. This function is best performed by a representative standing committee. For this reason, the chairman, in accepting his appointment, places his services and those of his committee at the disposal of the Bureau of Standards for the prompt and careful consideration of all questions which may arise when the program is put into actual use.

A committee that quickly and accurately reflects the wishes of the majority of its industry and, through its chairman, promptly disposes of matters referred to it is a practical insurance against any serious difficulty in the adoption of a commercial standard.

The standing committee must recognize that the Department of Commerce has no "police powers" to compel the acceptors to adhere strictly to the letter of the recommendation. Unanimous adoption by the general conference indicates a recognition of the benefits inherent in standardization. If this fact is properly emphasized, the acceptors should be equally willing to follow the program in all cases where it is applicable.

While the recommendation is in effect, the standing committee is to receive all information showing departures and to apply such corrective measures as appear to be in the best interest of all concerned.

\section{YOUR COOPERATION}

As a producer, distributor, or consumer of some of the commodities which have already been simplified or standardized, you are in a position to add impetus to this method of eliminating waste. The first step in that direction is to record your intention to adhere, as closely as circumstances will allow, to one or more of the existing recommendations, other than those you have already accepted.

You will, of course, want to examine the schedules before signing. The commercial standards group will, therefore, furnish a copy of any recommendation which you wish to consider with a view to its adoption. Publications no longer available in this manner can be purchased, for a few cents each, from the Superintendent of Documents, Government Printing Office, Washington, D. C. (We will furnish detailed price list on request.) 
When you have reached a decision, fill out the acceptance form on page 13, check the proper items on page 14, detach the sheet, and mail it to the commercial standards group, Bureau of Standards, Washington, D. C. In making your selection remember that simplified practice and commercial standardization apply not only to the things you sell but to the things you buy. On the support accorded by the consumer depends, in a large measure, the success of these waste-elimination programs.

The receipt of your signed acceptance will permit the listing of your organization in new editions of the recommendations you have checked. Any proposed revisions will be submitted to you for approval prior to publication.

This support is entirely voluntary and applies to stock items. It is not meant to interfere with the purchase or sale of such special sizes and types as are sometimes required to meet unusual conditions.

Trade associations and individual companies often distribute large numbers of the printed booklets for the information and guidance of their business contacts. In such cases it is possible to extend the scope and degree of adherence by urging each recipient to send in an acceptance. Bear in mind that the practical value of any simplification or standardization is measured by the observance it receives. A number of the simplified-practice recommendations have already secured an adherence of more than 90 per cent, by volume, of annual output. If each producer, distributor, and consumer will do his part toward discarding nonessentials and specify simplified or standardized lines when buying, adherence will approach 100 per cent. Obviously the higher the adherence to each specific simplification or standardization project the greater will be the benefits to all concerned. 

NOTE.-The information requested in footnotes 1 and 2 is essential to the proper listing of your organization in future editions of the printed bulletins.

\section{ACCEPTANCE OF COMMERCIAL STANDARDS}

Date

The Bureau of Standards,

Washington, D. C.

SiRs: We, the undersigned, hereby accept the commercial standards checked on the reverse side hereof ${ }^{1}$ as our standards of practice beginning

in the production, ${ }^{2}$ distribution, ${ }^{2}$ and consumption ${ }^{2}$ of the standardized lines.

We will use our best effort to secure their general adoption.

Signed

Title $^{3}$

Company $^{3}$

Street address ${ }^{3}$

City and State ${ }^{3}$

1 Be particular to indicate which commercial standards you are accepting by checking the list on the reverse side of this form.

2 Please designate by drawing lines through those which do not apply.

8 Kindly typewrite or print. 


\section{COMMERCIAL STANDARDS}

CS No.

1-28. Clinical thermometers.

2-29. Surgical gauze. (In preparation.)

3-28. Stoddard solvent.

4-29. Staple porcelain plumbing fixtures.

5-29. Steel pipe nipples.

6-29. Genuine wrought-iron pipe nipples.

7-29. Standard weight malleable iron or steel unions. (In preparation.)

8-29. Plain and thread plug and ring limit gage blanks. (In preparation.)
CS No.

9-29. Template hardware. (In preparation.)

10-29. Brass pipe nipples.

11-29. Regain of mercerized cotton yarns. (In preparation.)

12-29. Domestic and industrial fuel oils. (In preparation.)

13-30. Dress patterns. (In preparation.)

14-29. Boys' blouses, waists, shirts, and junior shirts. (In preparation.)

15-29. Men's pajamas. (In preparation.) 
